\title{
ADVANCES IN PEACH, NECTARINE AND PLUM PROPAGATION ${ }^{1}$
}

\author{
NEWTON ALEX MAYER ${ }^{2}$, VALMOR JOÃO BIANCHI ${ }^{3}$, \\ NELSON PIRES FELDBERG ${ }^{4}$, STEFANO MORINI ${ }^{5}$
}

\begin{abstract}
Nursery trees of stone fruits (Prunus spp.) are traditionally produced by union of two distinct genotypes - the rootstock and the scion - which, by grafting, form a composite plant that will be maintained throughout of all plant life. In Brazil, the rootstocks are predominantly seed propagated and therefore usually results in heterogeneous trees for vigor and edaphic adaptation. However, with advances in rootstock breeding programs that released cultivars and certification in several countries (notably in Europe), the system will come gradually evolving for vegetative propagation (cuttings and tissue culture) and use of seeds of selected rootstocks with specific characteristics and potted nursery trees production. For scion cultivar propagation, the budding system (with its many variations) has predominantly been adopted in major producing countries. This review had as objective to comment main propagation methods adopted for rootstocks and scion in peach, nectarine and plum, and recent technical progress obtained as well as the needs of improvement for nursery tree production.
\end{abstract}

Index terms: Prunus spp., seeds, cutting, grafting, air layering, tissue culture.

\section{AVANÇOS NA PROPAGAÇÃO DO PESSEGUEIRO, NECTARINEIRA E AMEIXEIRA}

RESUMO - Mudas de frutíferas de caroço (Prunus spp.) são tradicionalmente produzidas pela união de dois genótipos distintos - o porta-enxerto e a cultivar-copa - que, por meio da enxertia, formam uma planta composta. No Brasil, os porta-enxertos são predominantemente obtidos de sementes, normalmente resultando em plantas com heterogeneidade de suas características. Com os avanços nos programas de melhoramento genético de porta-enxertos, lançamentos de cultivares e programas de certificação de mudas em diversos países (notadamente na Europa), o sistema vem gradativamente evoluindo para a propagação vegetativa (estaquia e cultura de tecidos), uso de sementes de genótipos selecionados com características específicas e produção de mudas em embalagens. Para a propagação das cultivares-copa, a enxertia (com suas diversas variações) tem sido predominantemente adotada nos principais países produtores. O objetivo desta revisão bibliográfica é abordar os principais métodos de propagação adotados para porta-enxertos e para copas em pessegueiro, nectarineira e ameixeira, e os avanços técnicos obtidos, bem como as necessidades de melhorias para a produção de mudas de qualidade.

Termos para indexação: Prunus spp., semente, estaquia, enxertia, alporquia, cultura de tecidos.

\footnotetext{
1(Paper 123-16). Received September 21, 2016. Accepted January 23, 2017.

${ }^{2}$ Agricultural Engineer Dr., Embrapa Clima Temperado, BR 392, km 78, Caixa Postal 403, CEP 96010-971, Pelotas, Rio Grande do Sul State, Brazil. E-mail: alex.mayer@embrapa.br

${ }^{3}$ Agricultural Engineer Dr., Universidade Federal de Pelotas, Department of Botany, Institute of Biology, Campus Capão do Leão, CEP 96010-900, Caixa Postal 354, Capão do Leão, Rio Grande do Sul State, Brazil. E-mail: valmorjb@yahoo.com

${ }^{4}$ Agricultural Engineer M.Sc., Embrapa Escritório de Canoinhas, Rodovia BR 280 Km 231, Caixa Postal 317, CEP 89460-000, Canoinhas, Santa Catarina State, Brazil. E-mail: nelson.feldberg@embrapa.br

${ }^{5} \mathrm{PhD}$., Pisa University, Department of Agriculture, Food and Environment. Via Del Borghetto, 80, 56124 Pisa, Italy. E-mail: stefano. morini@unipi.it
} 


\section{INTRODUCTION}

The genus Prunus belongs to the Rosaceae family and includes the species commonly called stone fruit, because the seed is protected by a rigid stone called the endocarp. Globally, the most important stone fruits are peach, nectarine, almond, apricot, cherry, European and Japanese plums. In Brazil, the peach tree and, to a lesser extent, the Japanese plum tree and the nectarine tree are the only stone fruits that have commercial importance, which is why they will be addressed in this review.

Peach and nectarines are classified as Prunus persica (L.) Batsch, and present a wide range of climatic adaptation. Due to the multiplication by seeds for hundreds of years, they were widely dispersed to diverse regions of the world, where they passed through local selections. This process, followed by intentional breeding, produced a wide range of genotypes that can be grown from tropical regions, with about 50 hours of annual chilling accumulation $\left(\leq 7.2{ }^{\circ} \mathrm{C}\right)$, to areas with winter temperatures below $-30{ }^{\circ} \mathrm{C}$, accumulating 1,200 hours of annual chilling (OKIE, 2006a).

The peach tree has a number of chromosomes $2 n=16$ and most of the cultivars are self-fertile. However, cross pollination rates of up to $33 \%$ may occur, depending on existing relief, climate and entomofauna conditions (MILLER et al., 1989). Thus, if the seeds from these fruits are used for multiplication, there will be considerable genetic variability among the seedlings, an undesirable characteristic for the formation of commercial orchards. Table 1 lists the top 15 peach and nectarine producing countries (FAO, 2016a).

The plums are divided into two groups: a) the European hexaploids $(2 n=48, x=8), P$. domestica L., which are generally self-fertile, better adapted to colder regions and usually demanding in more than 1,000 hours of annual chilling accumulation, whose fruit can be consumed in natura or dehydrated; b) and the diploid Japanese $(2 n=16)$, P. salicina Lindl., which are in fact of Chinese origin, with lower chilling requirement (usually between 500 and 800 hours per year), that require cross-pollination for flower fertilization, whose fruits are normally consumed fresh (OKIE, 2006b). In Brazil, it is estimated that the area planted with plums is around 3,500 ha. Table 1 shows data for the 15 major plum producing countries (FAO, 2016b).

The major advances in plant cloning have occurred in the last 100 years (PREECE, 2003). Although the types of grafting and cuttings used today were already well known at the beginning of the last century, notable contributions have since emerged, especially in the areas of sanitation and disease control, infrastructure technology for clonal propagation, as well as the discovery of plant growth regulators and the role of juvenility, knowledge about chimeras and the development of in vitro culture and micropropagation techniques (PREECE, 2003; HARTMANN et al., 2002).

Based on the premise that the use of quality nursery trees is the basis for a modern and competitive fruit growing, this bibliographic review aims to address the main propagation methods used in peach, nectarine and plum tree (rootstock and scion) as well as recent advances in the area and improvement needs.

\section{Prunus spp. PROPAGATION AND RESEARCH ADVANCES IN BRAZIL}

\section{Background}

The peach tree was introduced in Brazil in 1532 by Martim Afonso de Souza, through seedlings brought from the Madeira Island and grown in the São Vicente Captaincy, in the present state of São Paulo. Cultivated for approximately 400 years only in domestic orchards, the peach tree only gained economic importance in the states of São Paulo and Rio Grande do Sul from the 1940s. At the same time, Brazilian peach breeding programs were initiated by Dr. Orlando Rigitano (1940s), at the Agronomic Institute of Campinas, state of São Paulo, and by Dr. Sérgio Sachs in 1953, at the former Phytotechnical Station of Taquari, in the state of Rio Grande do Sul (FRANZON; RASEIRA, 2014), who also had an important role in the improvement and diffusion of the grafting technique in stone fruit trees.

In Brazil, probably the first peach and plum trees grafts produced on a commercial scale date from 1887, produced by Quinta Bom Retiro Nursery, located in the Retiro Colony in Pelotas, RS. According to the journalist Henrique Mello, editor of the newspaper "A Pátria", from Rio de Janeiro, Quinta Bom Retiro was "the first South American establishment in the genre" (AMBROSIO PERRET \& Cia. Ltda., 1937). Another important milestone was that in the 1940s a farmer in Pelotas noted good productivity, adaptation and rusticity in a peach tree that has grown from pits thrown to the ground. This material was named 'Aldrighi' and was multiplied by seeds for several years, boosting peach tree cultivation in the southern of Brazil and also served as the basis for the "gaucho" breeding program for industrialization (FRANZON; RASEIRA, 2014). Due to the abundant availability 
of seeds in the industries, 'Aldrighi' was also widely used for the production of rootstocks until the 1970s (MAYER et al., 2014). With the launch in 1966 of the scion cultivar Capdeboscq, destined to the industrialization, and its large-scale cultivation in the region of Pelotas-RS, the pits of this cultivar also began to be used for the production of rootstocks. Currently, since the cultivar Capdeboscq is no longer commercially cultivated, the availability of its seeds is restricted only to nurseries that have plants of this cultivar for the purpose of producing rootstocks.

With the advances in genetic breeding program and launch of several scion cultivars intended for industrialization, the genetic variability of the seeds (pits as a residue process) available in the processing industries has become increasingly pronounced. As there were no studies focused on the development and launching of rootstock cultivars for several decades, producers and nurserymen continued to use these pits mixtures for the production of rootstocks, which resulted in heterogeneity and lack of knowledge of the genetic identity of the plant radicular system in orchards (MAYER et al., 2014). Considering that the genetic improvement of scion cultivars searches for earlier genotypes and low-chill requirement, the germination of the seeds of these new cultivars has been gradually reduced due to the incomplete development of the embryo. Therefore, the use of these seeds to produce rootstocks results in impairment of root system quality and reduction of orchard longevity (MUDGE et al., 2009). There is evidence that the use of pits varietal mixtures from the processing industries in the production of rootstocks also contributes to the aggravation of the Peach Tree Short Life (PTSL) symptoms, one of the main agronomic problems of the peach culture in Rio Grande do Sul (MAYER; UENO, 2012).

The propagation of species of the genus Prunus spp. (especially peach and Japanese plum) is a subject well studied by Brazilian research. Only in the postgraduate courses of the Federal University of Pelotas (UFPel), this subject was the research target in 40 master's thesis and / or Doctoral thesis in the period between 1980 and 2014, and the propagation by cuttings $(40 \%)$ and tissue culture $(40 \%)$ are the most studied methods. However, few studies have evaluated the performance of nursery trees propagated by these methods under field conditions. In recent years studies have begun to evaluate the potential of using new rootstocks in relation to different propagation methods and to overcome problems associated with biotic and abiotic stresses that compromise the production of orchards. In bibliographical reviews in the Annals of the Brazilian
Congresses of Fruitculture in the period 2000-2014 (Figures 1a and 1b), it was verified that $0.77 \%$ of the 10,049 articles involved propagation in Prunus spp. In the Brazilian Journal of Fruitculture (RBF) (Figures 1c and 1d), in the same period, only 1.73\% of the 2,433 publications involved propagation in stone fruit trees.

Based on these data, some aspects call attention, such as the gradual decrease of publications on propagation in Prunus spp. in the period considered, both in the congresses as in the RBF, besides the predominance of researches with cuttings and tissue culture methods. The low adoption of the information generated by the research on propagation in stone fruit, by the nurserymen and fruit growers, certainly contributes to the reduction and / or discouragement of research in the area. The second aspect reveals the very low research application in the productive sector, since rare Brazilian commercial orchards are formed with nursery trees produced by cuttings, as well as the lack of orchards formed by material cultivated in vitro. Paradoxically, the quality of most of the nursery trees commercialized in Brazil still leaves much to be desired, especially in the sanitary, genetic aspects and morphological pattern.

Brazil already managed to grow 24,507 ha with peach trees in 2003 , but this area has gradually decreased, being 18,091 ha in 2013 (Table 1). Only five Rio Grande do Sul municipalities (Pelotas, Canguçu, Pinto Bandeira, Morro Redondo and Farroupilha) account for $42.78 \%$ of this area (IBGE, 2016). Regarding the market of stone fruit nursery trees annually produced and commercialized in our country, there are no official data, and in addition, several fruit growers produce their own nursery trees, some nurseries are not registered in the RENASEM (National Seeds and Nursery Trees Registry) or do not declare the number of trees produced, which makes impossible detailing and generates an alert to the potential risks that may result from this lack of control, especially in relation to the introduction and spread of diseases. However, it is estimated that the demand for stone fruit nursery trees is somewhere between 2 and 2.5 million per year, which is fully met by domestic production.

\section{Propagation methods of rootstocks and scion cultivars}

When a stone fruit tree species is propagated, the final objective is to obtain material destined and suitable for planting, that is, a seedling or a nursery tree. Didactically, to achieve this goal, there are four possibilities, which may involve one or more methods of propagation: 1) using seeds: the product 
will be a seedling, i.e. a plant called "ungrafted" or "frank", whose use is restricted only to breeding programs due to juvenility and genetic variability among individuals; 2 ) scion grafted over a rootstock obtained from seed: the product is called nursery tree and involves a grafting method (vegetative propagation) of the scion cultivar over a rootstock produced by seed germination; 3 ) scion grafted over a clonal rootstock: the product is also called nursery tree, however it involves a grafting method of the scion cultivar over a clonal rootstock, which may have been obtained by cutting, layering or tissue culture; 4) own-rooted nursery tree: in this case there is no grafting and no rootstock. Therefore, the nursery tree will be formed by a single genotype, propagated by any vegetative method that allows the formation of adventitious roots.

Particularly in the production of rootstocks, the use of seeds still predominates, but there is great potential for the use of vegetative propagated material. Cloning (by cutting or in vitro) has been stimulated by several research projects, but at the commercial level, the use of clonal rootstocks still has very little importance in Brazil.

Next, the main propagation methods researched and adopted in peach, nectarine and plum trees in Brazil will be discussed.

\section{a) Seed propagation}

Currently, the propagation of scion genotypes by seeds is restricted and used only in the initial phase of breeding programs, when it aims at obtaining genetic variability. However, the use of seeds is widely disseminated for the rootstocks production, being the main method used, not only in Brazil, but in several countries.

In the production of rootstocks, some Brazilian nurserymen already adopt genotypes with some type of genetic control of the propagation material, through proper mother trees for the purpose of seed production. In the nursery, the sowing of the pits is done in lines, from May to June, and the budding can be carried out between the months of November and January subsequent.

However, the use of pits of late maturing peach scion cultivars, usually obtained from the residue of the industrialization process, is still a practice adopted in most of the "gaucho" nurseries (MAYER; ANTUNES, 2010). In this situation, the pits are kept in the shade under the tree canopy from December to May, which, through fermentation, action of biotic and climatic agents, promote the decomposition and drying of the pulp adhered to the pit. These factors contribute to reduce the physiological quality of the seeds and / or to prevent embryos that, together with the physical resistance of the pits and the fact that they are not broken, result in low germination percentages, usually less than 50\% (MAYER; ANTUNES, 2010). The seedlings obtained in this way are not recommended for the production of rootstocks, because they constitute a varietal mixture of peach trees not selected for this purpose, which will be reflected in differences between the root systems of the future orchard plants, besides the unpredictability of their reactions to biotic and abiotic soil conditions (MAYER et al., 2014).

The Brazilian research has been developing and adapting alternatives to improve this rootstock production system (SOUZA et al., 2016). However, its adoption on a commercial scale requires investments and conceptual, managerial and technical changes, in the nurseries; in addition to that the customers (fruit growers) must begin to demand nursery trees of genetic and sanitary quality and with a guaranteed morphological standard. Probably these changes are the main needs to effectively make progress in the stone nursery tree production.

In the State of São Paulo, the 'Okinawa' $(P$. persica) rootstock is the most used and, because it has a very hard endocarp, needs to be broken. The seeds are packed in boxes containing vermiculite, sawdust or cotton, treated with fungicide, and stratified in refrigerators or cold rooms, for 50 to 60 days. These treatments allow obtaining greater homogeneity and percentages of germination, which normally vary between 70 and 100\% (PEREIRA; MAYER, 2005; MAYER; ANTUNES, 2010).

The production of stone fruit tree rootstocks by seeds is possible, because it is relatively easier and cheaper, compared to the methods of cloning, such as cutting or in vitro propagation (MAYER et al., 2014). However it is necessary to use seeds of genotypes selected specifically for this purpose, which present desired characteristics such as high percentage of germination, homogeneity of seedlings for vigor and agronomic performance, resistance to pests and soil diseases, good compatibility of grafting with canopy cultivars, which are important characteristics and, per se, justify the use of rootstocks in fruit growing. Another advantage of seedling production is related to the fact that some pathogens (bacteria, viruses, viroids and phytoplasmas) that occur in different Prunus species have a lower rate of transmission or are not transmitted to offspring via seeds or pollen (BARBA et al., 1999), resulting in the production of rootstocks with better sanitary quality when compared to cloning, mainly by cuttings.

Some introduced or selected rootstocks are 
currently available in Brazil, which can be propagated by seed or by cutting, such as the cultivars Okinawa, Flordaguard, Nemared, Sharpe, Tsukuba series (1,2 and 3), which present resistance to some species of Meloidogyne spp. and positive effects on canopies and plant longevity (SHARPE et al., 1969; LU et al., 1999; PAULA et al., 2011a; PAULA et al., 2011b; ROSSI et al., 2002). Several genotypes, derived from controlled crosses, are under evaluation at the Federal University of Pelotas, mainly aiming at the selection for resistance to Meloidogyne spp. (PAULA et al., 2011b), low vigor, low-chill requirement, high rate of seed germination and homogeneity of seedlings (ALMEIDA et al., 2015, MARTINS et al., 2011; SCHMITZ et al., 2014, SOUZA et al., 2016).

Although it is not usual, the methodologies for germination tests, tetrazolium test, determination of moisture content, as well as the maximum batch and sample size for purity analysis in Prunus spp. seeds, are described in Rules of Seed Analysis (BRASIL, 2009).

\section{b) Vegetative propagation methods}

- air-layering: it is a simple method to clone species of the genus Prunus spp. and is one of the possibilities that can be used for rootstocks (CASTRO; MAYER, 2009) or for peach scion cultivars (CASTRO; SILVEIRA, 2003) and of plums (CASTRO; MEDEIROS, 2007). The method consists of partial or total annealing (1.0 to $1.5 \mathrm{~cm}$ width) in the base of woody branches of the mother trees, followed by injury treatment with indolbutyric acid at 3,000 mg. $\mathrm{L}^{-1}$ and wrapping with moist vermiculite and plastic bag. After rooting, the airlayers must be removed from the mother tree and transplanted into containers with substrate. The airlayering is a method that does not depend on specific infrastructure, however the low yield per mother tree and the need for some technical knowledge of the method are its main disadvantages (BIANCHI et al., 2014), reasons why it is not commercially used in the production of stone nursery trees in Brazil.

- cutting: it is the most important method of cloning to several crops, and the formation capacity of adventitious roots is a prerequisite for success (HARTMANN et al., 2002). Cuttings are prepared portions of the plant for the purpose of propagating and, in the case of species of the genus Prunus spp., can be obtained from woody, semi-woody or herbaceous shoots. In Brazil, although this method has been extensively researched (Figure 1), very few nurserymen use the technique, being rare the orchards with Prunus spp. whose nursery trees have been produced by this method. In Europe, due to advances in genetic breeding of rootstocks and the availability of interspecific hybrid rootstocks (which have the greatest potential for adventitious rooting), cloning by woody cuttings is a known, cheap method and used in a commercial scale.

The adventitious rooting of Prunus spp. cuttings is influenced by genetic factors, management of the mother tree and of the rooting environment, collection season and degree of lignification of the cuttings. Due to all these factors, the results have been quite variable; however, it is possible to obtain rooting percentages higher than $70 \%$ with herbaceous, semi-hardwood or woody cuttings of scion peach tree cultivars (DUTRA et al., 2002; MINDÊLLO NETO et al., 2008), scion plum trees (MINDÊLLO NETO et al., 2006), of $P$. persica rootstocks (NACHTIGAL, 1999; TOFANELLI et al., 2005) and rootstocks of other species or interspecific hybrids of Prunus spp. (MAYER et al., 2001; MAYER et al., 2013; RADMANN et al., 2014a; MAYER et al., 2015). As a general rule, it is recommended that adequate fertilization (especially nitrogen) in the mother trees, drastic winter pruning in these plants to obtain vigorous new shoots, rapid immersion of the cutting base in indolbutiric acid solution (between 1,000 and $4,000 \mathrm{mg} \mathrm{L}^{-1}$ ), the availability of intermittent mist system, the use of containers and substrates that allow good drainage during rooting, are indispensable conditions for the success of the adventitious rooting of herbaceous cuttings, being this type of cutting that allows the best results in Prunus spp. propagation. With planning and technical knowledge of the subject, it is possible to obtain adventitious roots of excellent quality and rooting percentages higher than $90 \%$, with herbaceous cuttings in the summer. One variation of the method is the use of herbaceous or semi-herbaceous minicuttings, with two or three buds and a half-leaf (TOMAZ et al., 2014).

In general, woody cuttings of plum or interspecific Prunus hybrids rooted more easily compared to peach trees, and the environmental conditions of the rooting phase (autumn or winter) are decisive for success or failure. However, plums also rooted more easily when using herbaceous shoots compared to woody ones (OKIE, 2006b).

The rooting of cuttings for rootstocks or own-rooted scion trees production is a reality commercially applied to the various crops in Brazil, such as grape, guava, olive, blackberry, eucalyptus and various silvicultural, ornamental and medicinal species, bringing as main advantages the maintenance of the genetic characteristics of the original plant, the independence of seeds and the reduction of the time 
for nursery tree production. In stone fruit trees, some studies were conducted in field conditions comparing the clonal rootstocks with those produced by seeds, which proved that the clonal ones present similar or superior performance (PEREIRA; MAYER, 2005; MAYER; PEREIRA, 2008; MAYER; PEREIRA, 2012; SOUZA, 2014). In evaluation of the root system distribution under field condition, no root fixation problem in the soil was observed in peaches 'Aurora-1' grafted on 'Okinawa' propagated by cuttings, compared to 'Okinawa' seed-propagated after 34 months of planting (MAYER et al., 2007).

On the other hand, obtaining own-rooted scion cultivars (without rootstocks) by cutting or in vitro has as the main advantage reducing the time to its production, from only six to eight months, reducing in one year the permanence in the nursery. Souza (2014) evaluated own-rooted 'Maciel' peach trees for three years in field condition and found that the growth, phenology, yield and fruit characteristics were equivalent or superior, compared to the trees grafted on 'Okinawa' seedlings.

Plants obtained by own-rooted peach, nectarine and Japanese plum scion cultivars, as well as scion cultivars grafted on several clonal rootstocks, are being evaluated in 18 observation units under different edaphoclimatic conditions that allow the cultivation of stone fruit trees in Brazil. This study is part of an inter-institutional project, led by Embrapa Clima Temperado (Pelotas-RS), and aims to make regional recommendations for clonal rootstocks, as well as answering the key question of this theme: Do own-rooted scion nursery trees present technical feasibility to improve fruit quality and form productive and long-lived orchards?

The rooting of herbaceous cuttings has been used as a method to rescue accesses of interest in commercial orchards since 2007, by Embrapa Clima Temperado researchers, in order to shorten the time required in the selection process of rootstocks that are potentially tolerant to PTSL. In PTSL asymptomatic trees, located among PTSL symptomatic trees, the cutting is carried out below the grafting point, promoting intense and vigorous sprouting of the rootstocks, an essential condition for the success of the rooting of its herbaceous cuttings (MAYER et al., 2009).

However, it is necessary to emphasize that, despite the advances obtained by the research on the propagation of stone fruit, the diffusion of this knowledge in the productive sector is very limited, and investments are also necessary in the structure of the nurseries. In addition, the lack of a national certification program for the production of nursery stone fruit trees increases the chances of propagation of contaminated plant material, mainly by viruses and bacterioses.

- grafting: there is evidence that grafting was practiced by the Chinese for at least 2,000 years BC. This propagation technique involves the creation of a genetic system composed of the union of two (or more) distinct genotypes, that each component will maintain its own genetic identity throughout the life of the grafted tree. In general, interclonal / intraspecific grafts are almost always compatible; Interspecific / intrageneric grafts are generally compatible; Intrageneric / intrafamilial grafts are rarely compatible; and interfamilial grafts are essentially always incompatible (MUDGE et al., 2009).

In Brazil, commercial nursery trees of stone fruit are obtained, in the majority, through the scion active bud budded on $P$. persica seedlings, in the nursery maintained under field conditions (SCHMITZ et al., 2014; MAYER et al., 2014). This system is applied to the production of peach, nectarine and Japanese plum nursery trees, and the process starts obtaining the pits and with the stratification of them (at room temperature and in the shade or in cold chambers), followed by sowing them in the field, in the months of May or June. The seedlings will be able to graft in the months of November to January, when the manual grafting is done by budding, being the " $\mathrm{T}$ " inverted or normal, the main types adopted (MAYER; ANTUNES, 2010; BIANCHI et al., 2014). From that period, the grafted trees grow in the field until the months of July and August, period that they are in vegetative rest, which is recommended for the pull-off and sale in the form of bare root, to the fruit growers. In this system of nursery tree production, that persists in the south of Brazil since the beginning of the grafting practice (AMBROSIO PERRET \& CIA. LTDA., 1937), the average time to obtain trees is approximately 18 months, being a relatively long period.

An important aspect that deserves attention is the field production system. It is known that there are no registered nematicides for stone fruit nursery trees in Brazil and, therefore, the possibilities of ensuring that the trees produced in this system are free from nematodes are quite restricted. Alternatives to this system may be the production of nursery trees in plastic bags or citropots on benches (PEREIRA; MAYER, 2005; MAYER et al., 2014) or suspended canalethes (TOMAZ et al., 2014) containing substrate free of pests, diseases and weed seeds. Some more technical Brazilian nurseries already use these systems on a commercial scale. 
In general, Japonese plums are more difficult to propagate by budding compared to peach tree, possibly due to the smaller, tenderer bud and the scion bud shoots have a thinner bark (OKIE, 2006b). In the main producers countries of European plums, grafting is mainly carried out on seedlings of 'Myrobalan' or other selections propagated by cutting or in vitro ('Marianna 2624', 'Marianna GF8-1', 'Brompton', 'Damas' and 'St. Julien'), while for Japanese plums, peach trees are usually used as rootstock, with 'Nemaguard' and 'Lovell' being the most recommended in California (OKIE, 2006b). In Brazil, plum nursery trees are budded on seed-propagated peach rootstocks, being 'Okinawa', 'Capdeboscq' or mixtures of pits from the canning industries, the materials used. However, new alternatives of clonal rootstocks for Japanese plum cultivars are being studied.

Although it is not yet a well-studied and known technique in stone fruit trees, it is possible to produce nursery trees by simultaneous grafting with cuttings, a technique also known as table grafting. Studying this technique in herbaceous cuttings of 'Okinawa' grafted with 'Aurora-1' scion peach, Nachtigal (1999) obtained the best results when budding in inverted " $\mathrm{T}$ " was held at the rooted cutting, at 90 days after rootstock transplantation, obtaining $71.43 \%$ of bud taken and nursery trees with $50 \mathrm{~cm}$ height in only 10 months.

- tissue culture: the in vitro propagation of rootstocks is a reality in several countries of Europe and the United States, for several fruit species, including Prunus spp.. In South America, mainly in Chile and Argentina, rootstocks used for peach, plum and cherry trees are propagated in vitro (ALMADA et al., 2013).

In Brazil, several studies have demonstrated the possibility of in vitro cultivation of several peach rootstocks as 'Cadaman ${ }^{\circledR}$ ' and 'Barrier $1^{\circledR}$ (COUTO et al., 2004), 'Tsukuba 1', 'GxN9' and 'Flordaguard' (RADMANN, 2009ab; RADMANN et al., 2011). However, the best results were obtained with the plum rootstocks 'Julior', 'Mr. S. 1/8', 'Mr. S. 1/14' (CAMPOS et al., 2007) and 'Mr. S. 2/5' (ROCHA et al., 2007ab), with satisfactory multiplication, rooting and acclimatization rates (RADMANNN et al., 2014b).

Although the low in vitro multiplication rates of $P$. persica rootstocks in Brazil are still a limiting factor for this type of clonal propagation, the use of plum rootstocks has a potential for immediate use, since the available genotypes ('Marianna 2624', 'Myrobalan 29C', 'Julior', 'Mr. S. 2/5', among other) can be propagated with relative easiness, because according to Okie (2006b), plums are generally easier to propagate in vitro and by cutting than other species of Prunus spp.

It should also be noted that some plum rootstocks such as 'Ishtara', 'Mr. S. 2/5'and 'Julior' present good graft compatibility with peach canopy cultivars, influencing plant vigor and fruit quality, both in peach and plum trees (SANSAVINI et al., 2004; REMORINI et al., 2005; SCALZO et al., 2006; MURRI, et al., 2012), besides being more tolerant to soil hypoxia conditions (MESCHIMIDT et al., 2015), a problem that affects most of the Prunus orchards in the southern region of Brazil, due to the high rainfall in the winter and spring period.

Although the in vitro propagation of some rootstocks presents short-term potential of use, the responses of these genotypes to the field need to be evaluated, mainly to infer about the adaptation and graft compatibility with different scion cultivars commonly used in Brazil. Another important point to be considered is the high production cost of in vitro plants, due mainly to some reagents used in the process and the production structure (laboratory), a factor that increases the unit value of the rootstock and makes it difficult to accept this type of product in the production chain.

Legal and supervisory aspects in the Prunus spp. nursery tree production in Brazil

The stone fruit nursery tree production in the country from an organized system began with the publication of the Law No. 6,507 of December 19, 1977 that provided for the inspection and supervision of the production and trade of seeds and seedlings, with the objective of guaranteeing, on the basis of official standards, the quality of the propagules produced and commercialized. The validity of this legislation occurred until the publication of Law No. 10,711 of August 5, 2003, regulated by Decree No. 5,153, of July 23, 2004, with the purpose of establishing the National System of Seeds and Nursery Trees, in order to guarantee the identity and quality of the propagation and plant breeding material produced, marketed and used throughout the national territory. They were also instituted:

- National Register of Seeds and Nursery Trees - RENASEM. To engage in any activity of production, processing, packaging, storage, analysis, trade, import and export of seeds and nursery trees, the physical and legal entities are required to enroll in RENASEM;

- National Register of Cultivars - RNC. The RNC enables the production of seeds and nursery trees of the cultivars registered in it, besides 
indicating the maintainers of each cultivar.

The Normative Instruction No. 24 of December 16, 2005, deals with the basic guidelines to be followed in the production, marketing and use of nursery trees throughout the national territory, both certified and uncertified. In it, two classes of nursery trees are planned, according to the production process: Certified Nursery Trees (submitted to the certification process) and Nursery Trees (not certified). The certification of nursery tree production aims quality control at all stages of the process meeting the specific norms and standards to each crop. However, norms and standards for stone fruit tree grown in the country have not yet been published. Despite the existence of legislation, it is common the informal propagation and commercialization of stone fruit nursery trees, formed from pits obtained from the waste of canning industry, or from fruits that did not reach commercial standards and remained in the property, and from buds removed from commercial orchards, activity facilitated by inefficiency or lack of supervision of the nurseries. Thus, nursery trees formed with low quality propagation material and of unknown origin are marketed outside the legislation and are in many cases responsible for the spread of diseases, pests and poor morphological and physiological quality. Efforts will be necessary by public authorities to ensure that the productive sector recognizes and values the use of nursery trees produced by regulated nurseries, as well as the organization of industry leaders for the publication of Norms and specific Standards for stone fruit trees.

\section{Necessary advances in Prunus nursery tree production system in Brazil}

Although several researches have been carried out and some advances have occurred in recent years, we highlight some aspects that still need to be improved and established so that quality nursery trees can be effectively produced and marketed. Among them, we can highlight:

- to encourage nurserymen or nursery associations to set up their own clonal Gardens and mother trees, both for rootstocks and scion cultivars, with periodical genetic and sanitary control, in accordance with current norms;

- perform periodic inspection of nurseries, by competent organizations;

- in case of the production of rootstocks by seeds, to increase the dissemination of the existing knowledge about the fruit mechanical pulping, the drying, the pit breaking and their storage, the seed stratification and the sowing, aiming to increase the percentages of germination and disease reduction;
- to promote the production of potted nursery trees or in substrate benches, in nurseries with some type of protection (plastic, slat or shade scream), which will allow to stagger the hand labor, dilute costs, extend grafting periods and commercialization of nursery trees, reducing climatic and market risks;

- to study the effects of clonal rootstocks in Brazil, aiming at regional recommendations;

- to carry out more field research to quantify the effects and longevity of own-rooted trees (produced by layering, cuttings or in vitro cultivation) of different scion cultivars, compared to the grafted trees;

- to make possible technically and economically the in vitro cultivation of stone fruit trees in Brazil, starting from clonal gardens and certified mother scion trees;

- to increase the information exchange and to establish partnerships between the public and private sectors involved in the production chain, aiming to stimulate genetic improvement and the establishment of observation units more directed to the demands of each micro-region.

\section{ADVANCES AND RECENT TRENDS OF Prunus PLANT PROPAGATION IN EUROPE}

European peach and plum orchards are sophisticated biological systems where each plant is a structural element characterized by specific genetic and sanitary requisites, high productive efficiency, precocious fruiting, easy canopy training, aptitude to exploit maximum benefit from natural and cultural energy inputs. Such remarkable plant performances depend firstly on the high nursery quality that the maiden plants have been attained thanks to the dynamic and continuous development of the research on plant biology, genetic and molecular biology, plant breeding, physiology, etc., occurred during the last 10 - 15 years. A significant contribute has derived also from the technological advancement of laboratory instrumentation that made possible to carry out deep analysis to acquire fundamental scientific information inconceivable yet few years ago.

Although plants nursery quality can be currently considered at the top in Europe, it is incessantly influenced by variable events, as the fluctuations of general economic situation of a country, the application of more advanced cultivation systems, the request of nursery plants with more specific qualitative characteristics, the need to reduce the costs of propagation and, in particular, the necessity of reducing or removing the negative side effects exerted by nursery techniques on 
environment and human health. Thus, the interest of the researchers is mostly oriented to point out appropriate nursery innovations, suitable to satisfy the continuous new requests from the nursery market.

\section{Plant nursery quality}

The first most important requirement of plant nursery quality to which European fruit growers give particular attention, is the genetic and sanitary status of the plant that is the true-to-type genotype and the absence of pathogen microorganisms (virus, bacteria, fungi). Moreover, a plant of good nursery quality has to show at least 3-4 well-structured roots, evenly distributed around the base of the plant stem, provided with thin absorbing rootlets. Good tissue differentiation of the plant crown and the presence of productive branches, distributed alongside the main shoot, are characters of high quality as well. These biological and agronomical peculiarities of plant nursery quality are the most important features that will affect the productive potential of a fruit orchard, all over its commercial life. They are mainly acquired during plant nursery management, starting from the right choice of plant materials, the techniques of propagation to utilize and the growth inducing procedures performed by the nurseryman to produce the new plants.

European States members have developed, during last years, own plants certification schemes to regulate genetic and sanitary quality of plant propagating material and plant nurseries. To allow to States members common benefits on this matter, all certification schemes flowed into a Community scheme which incorporated many of the basic principles of each State member. Two marketing plant categories are authorized. The lower category, designated as CAC (Conformitas Agraria Communitatis), less restrictive, according to which the plants have to compulsorily possess minimum standard characters. CAC is based on a Document of Commercialization accepted by all over the European countries, issued by the nurseryman himself. The nurseryman is responsible of such Document: he can avail of specialized laboratories to verify the plant sanitary status. A second voluntary higher category concerns also the genetic identification of the plants and it consists of Pre-basic, Basic and Certified grades. In Italy, for instance, it is in force a "certification of product", that is a National Voluntary System of Genetic and Sanitary Certification (SAVINO, 2006). The plants produced by the nursery farm derive for direct filiations from the original plant, formally and directly controlled by Dedicated Plant Health Services. Hence, the cultivar scion buds and the plant rootstocks that the nurseryman will utilize to produce the future budded maiden plants, come from mother plants that have passed through different phases strictly supervised: conservation of the original genotype, pre-multiplication and multiplication. During each phase, accurate and continuous obligatory monitoring of genetic and sanitary plant conditions is carried out by authorized institutions. At the end of certification procedure, the plants produced by nursery farms that adhere to the Voluntary System of Certification, are provided of a tag that attests the plant quality.

\section{Propagation techniques}

The peach, nectarine and plum plants, like the majority of fruit tree species, are genetically heterozygous and, therefore, they have to be propagated exclusively by vegetative methods to maintain a specific genotype (variety). The most adopted techniques in Europe are represented by budding or grafting onto suitable rootstocks. Plants obtained from self-rooted varieties have shown substantial limitations as concerns their adaptation to different types of soil, plant vigour, parasites resistance, etc. Moreover, the recent development of a wide range of rootstocks allowing the plants to overcome a number of biotic and abiotic plant stresses, and to control scion vigour, has induced the fruit growers to prefer budded or grafted plants in comparison to self-rooted plants as well. Furthermore, the possibility of controlling canopy growth and size by a suitable rootstock has been very attractive in the perspective of reducing management costs and also in better adapting the orchard to the current trend toward increased planting density even in highly fertile soils.

Consequently, seed propagation of peach and plum plants in Europe is restricted only to propagation of some rootstocks while varieties are absolutely propagated by vegetative techniques.

\section{Seed propagation}

Seed propagation is still widely adopted to propagate different recalcitrant Prunus rootstocks to vegetative propagating techniques, assuring that genetic variability does not compromise the quality of the grafted plants. This technique has low costs of management, pits can be easily supplied, propagation structures are relatively cheap and seedling nursery practices are simply performed. Moreover, seedlings lines with reasonable genetic homogeneity can be obtained by pits collected from seed-bearing mother plants self-pollinated. Some lines have been selected for different degrees of vigour, frost resistance, or 
reduced susceptibility or resistance to nematodes. 'Rubirà', 'Higamà' and 'Montclar' from France, and 'P.S. A5', 'P.S. A6' and 'P.S. A7' from Italy are some examples of selected lines (FIDEGHELLI et al., 2009).

Seed germination is enhanced by removing some types of seed mechanical and physiological barriers, for instance by pit scarification that improve tissue water imbibitions and gaseous exchanges, by seed leaching in water to remove growth inhibiting substances such as abscisic acid, by seed vernalisation at temperature of 3 to $5{ }^{\circ} \mathrm{C}$ for 10 to 12 weeks, by seed treatments with growth regulators as gibberellic acid $\left(\mathrm{GA}_{3}\right)$ to help the embryo in overcoming the physiological dormancy. Then, environmental conditions of nursery site, substrate nutritional and sanitary status, availability of macro and microelements, the presence of useful rhizosphere microorganisms such as bacteria and mycorrhizal fungi, and $\mathrm{pH}$, have a primary role in favouring seed germination and seedling developments. Soils previously used for peach plants should be avoided, in order to prevent the risk of replant disorders. As an alternative to fumigant methyl bromide, after its prohibition on 2005 by European Union, good results have been obtained by soil solarisation (KATAN and DEVAY, 1991) adopted to overcome replant problems in nurseries specialised for peach propagation (DI VAIO et al, 2001).

To obtain suitable size of peach and plum rootstock seedlings at budding or grafting time, the plants are adequately spaced on the row at field transplanting time. This stimulates the scion variety in producing well differentiated laterals between 40 and $60 \mathrm{~cm}$ from the soil as well. The laterals play an important role in performing the plant training system, such as the sprint palmette, free spindle, and delayed open centre, in which the laterals (branches) are used to build up precociously the framework of the first branches.

Still today a number of seedlings rootstocks are used for peach, nectarine and plum, such as common peach seedlings obtained from pits coming from Yugoslavia, Morocco (known as 'Missour'); 'Montclar Chanturgue', 'Rubirà' selected in France; 'P.S. A5', 'P.S. A6', 'P.S. B2' selected in Italy and produced by self-pollinated plants; 'Myrobalan' utilised for European and Japanese plum.

\section{Cutting propagation}

Many rootstocks suitable for peach and plum, as for instance 'Adesoto ${ }^{\circledR}$, ' 'Jaspi FERELEY ${ }^{\circledR}$ ', 'Julior Ferdor $^{{ }^{\mathbb{B}}}$, 'Myrobalan B', 'Myrobalan 29C', 'Mr.S. 2/5', 'Penta', 'Tetra', 'Marianna GF 8/1', 'Castore',
'GF 677', 'Polluce', 'Sirio', 'Barrier $1^{\circledR}$ ', 'Cadaman ${ }^{\mathbb{R}}$ Avimag', 'Citation ${ }^{\circledR}$ Zaipime', 'Ishtara ${ }^{\circledR}$ Ferciana', ((FIDEGHELLI et al., 2009) and ROOTPAC series by Agromillora Catalana, have shown quite satisfactory results when propagated by cutting. However, since the wide spreading of micropropagation, the use of cutting technique has been progressively reduced. Indeed, the difficult identification of the best cutting collection time, the short rooting pick, the unknown tissues physiological conditions favourable to adventitious rooting, the uneven effectiveness of auxin treatments, the mortality of cuttings during rooting and after transplanting in the soil (FIORINO; MATTII, 1992), are some of the problems that frequently occur in cutting propagation.

The use of hardwood cuttings can give remarkable results with rootstocks provided of high adventitious rooting capacity. In this case, cuttings collected for instance in October - December after a treatment with auxin and with temporary bottom heat, could be planted directly in the field where, in the presence of draining soil and mild temperature, they will root and grow up to right dimension for budding at the end of August - beginning of September. With this procedure it is possible to produce a dormant budded plant in only one year time.

Semi hardwood cuttings are generally collected from mid July to mid August and are provided of very young tissues and leaves. Thus, greenhouse environment conditions as the percentage of relative humidity and the ambient temperature and light, have crucial importance. In particular, light intensity and photoperiod have to be at a suitable level to allow cuttings photosynthetic activity and natural hormones synthesis. Peach semi hardwood or softwood cuttings have given satisfactory results with a number of peach rootstocks as 'PS B2', 'PS A6', 'GF 677', 'Cadman', 'Adafuel', 'Adarcia', 'Barrier 1' and 'Citation'. Nevertheless, the use of semi hardwood cuttings implicates a lengthening of the time required to obtain a rootstock plant suitable for grafting. Indeed, cuttings collected in the summer, considering 2 to 3 months the time necessary for rooting and field acclimatization, can only be budded at the end of summer of the following year, increasing the overall costs of cuttings management, comparing to those of hardwood cuttings.

In most of cases, cuttings are treated at the base with auxin (IBA, NAA or IAA) to increase rooting percentage, roots number and quality. An auxin basal application, for instance with $1,000 \mathrm{ppm}$ of IBA, combined with a leaf spraying with the same auxin at about $50 \mathrm{ppm}$, may results in higher rooting percentage and number of roots per cutting, even if a 
temporary bud bursting inhibition may be induced.

Treatments of cutting leaves with boron, potassium and manganese can likewise to increase rooting response, while manganese and iron may be particularly active in preventing early leaf senescence. Washing of the cuttings under running water for some hours before auxin treatment, can produce a beneficial effect on cutting rooting as well. Bottom heat and mist nebulisation still represent the main forcing treatments to support cutting metabolism and consequently rooting expression (HARTMANN et al., 2002).

Cutting propagation is actually easy to apply and needs relatively simple facilities and equipments, available to most of nursery farms. Nevertheless, the success of this technique applied to many important genotypes is, still today, strictly dependent from the possibility of overcoming some critical problems. Deeper knowledge on the physiological and molecular mechanisms that control adventitious rooting, could increase cutting reliability even for propagating recalcitrant woody species, making the use of the cutting a suitable alternative to other techniques of vegetative propagation. In this regard, many researches have demonstrated the possibility of improving rooting potential in microcuttings of different woody species, by rolB gene, Agrobacterimmediated transfer. (RADCHUK; KORKHOVOY, 2005; RAYYA et al., 2010).

\section{Micropropagation}

Micropropagation represents the most widely adopted method to propagate numerous peach and plum clonal rootstocks (MORINI, 2004). It has the great advantage of allowing the propagation of a high number of plants in a very short period of time and in an extremely small space. In addition, production scheduling has greater flexibility, compared to other propagation techniques, since micropropagation is independent from environmental and field cultural conditions. In vitro propagated plants are small sized and are easily transportable, are free from pathogenic microorganisms and less subjected to rigorous controls by customs health authorities and quarantine services. Beside the standard procedures of in vitro micropropagation, some innovations have been developed to improve cultures growth; in particular, good results have been obtained by temporary immersion systems (DAMINANO et al., 2005), by which the cultures are immersed in liquid culture medium for different times and intervals. The use of filtered vessels lids, allowing gas exchanges between endogenous and exogenous atmosphere, has shown to improve culture growth by reducing toxic gas accumulation inside the vessel and improving culture photosynthetic activity as well (GRIBAUDO et al., 2003; HASSANKHAH et al., 2014).

Although micropropagation has given remarkable results with many species, some critical points have still to be overcame as for instance the recalcitrance of some genotypes to in vitro cultivation, the high production costs due to expensive equipments as autoclaves, air flow cabinets, thermolight-controlled growth chamber, etc. and the appearance of genetic and phenotypic alterations of the micropropagated plants (somaclonal variations, DNA inheritable mutations, epigenetic variations not inheritable by DNA, chimeric variations).

In addition to micropropagation, the wide spreading of in vitro culture and the use of the bioreactors has amplified the perspectives of pointing out new propagation techniques, e.g. those based on the somatic embryogenesis process and artificial seed technique. Peach and plum currently appear to be rather recalcitrant to produce somatic embryos, but deeper knowledge in the future could make this process more efficient and suitable as alternative propagation technique for the above mentioned species as well. The great advantages of somatic embryogenesis are represented by its high potentiality in producing large amounts of plants in smaller room and shorter times compared to those required by micropropagation, the possibility of propagating genotypes which do not produce vital seeds, or produce only a few seeds or seeds with scarce germination capacity, the propagation of a specie even only from a few seeds. Somatic embryogenesis might be used to propagate species that still today be propagated by seed, as for instance some peach and plum rootstocks (ARBELOA et al., 2009), or other species where genetic variability does not compromises the plant quality.

\section{Budding and grafting}

Peach, nectarine and plum are propagated by budding and grafting which still represent the only techniques suitable to produce nursery plants on selected rootstocks and to maintain a specific cultivar genotype. T-budding is the most popular technique and a common practice in nursery due to its simplicity and low cost. A vegetative scion bud, collected preferably from virus-free mother tree shoots, is inserted in a T-cut performed on the stem of a rootstock of about 8-10 mm diameter and at 10$15 \mathrm{~cm}$ from the ground. T-budding has to be done when the rootstock plant is actively growing and the bark slips easily from the wood at the cambial zone. The latter requisite is the most important factor 
for the success of budding and the best period for T-budding in European countries is at the end of summer (dormant bud budding). Dormant T-budded maiden plants could be transplanted at the beginning of the following spring in the orchard field with two advantages: lower price of the plants and, the most important, an earlier and successful realization of the plant crown training system.

The T-budding can be also performed at the beginning of spring (vegetative bud) or beginning of summer (June budding). Vegetative bud budding represents a standard technique to propagate Prunus cultivar but, more frequently, it is utilized to recover rootstock plants where the graft union formation of the dormant bud budding failed. Compared to dormant budding, vegetative budding is less utilized by nurserymen because it is performed with completely dormant buds that have to be collected in the winter and stored at low temperature until budding time. June budding belongs to short cycle nursery techniques and it allows producing a maiden tree only in one year. It is performed in areas with mild winter and spring, where seeds are sown in winter and the rootstock plant can rapidly reach the right diameter for budding at the beginning of June (HARTMANN et al., 2002).

Satisfactory results are also attainable with chip budding carried out from end-Summer to endWinter. Chip budding differ from standard budding because it can be done independently from rootstock growth activity and it is often preferred even to dormant budding because it has greater flexibility in time execution, it is easy to perform and it allows to obtain high percentages of take.

Grafting techniques are based on the use of a scion that is a piece of few centimeters length of one year shoot, provided of two or three vegetative buds, properly inserted on the rootstock plant. Numerous types of grafting are available to nurseryman to propagate specific genotypes but only a few are mostly utilized for peach and plum. In the standard nursery procedures, cleft and triangle grafting are often utilized to recover plant rootstocks on which dormant budding failed to take. Grafting can be done regardless of the rootstock growth stage and normally it is performed at the end of the winter, beginning of the spring.

\section{Micrografting}

It is performed in vitro to recover fruit tree species from virus infection. A cultivar shoot tip of about $0.1-0.2 \mathrm{~mm}$ is aseptically collected and placed on the top of decapitated in vitro plantlets. After few weeks of culture, the graft union occurs and grafted plantlet can be transplanted. This technique has been adopted for the first time to restore virusaffected citrus trees. Subsequently, peach (BARBA et al., 1995), almond and cherry cultivars sensitive to prolonged heat treatments, have been recovered by some viral diseases. In peach, satisfactory percentages of plants have been released from Chlorotic Leaf Spot Virus (CLSV) and Prunus Necrotic Ring Spot Virus (PNRV). Recovery response to Prune Dwarf Virus (PDV) varied according to the viral strain. Different factors, as for instance the growth status of the mother plant, the rootstock genotype, the in vitro growth medium utilized, the micro-environmental conditions in the culture vases and inside the acclimatization greenhouse, can influence the success of this technique.

\section{Herbaceous grafting}

This technique consists of inserting a shoot tip of some millimeters length, collected from in vitro culture, on an in vivo grown young rootstock of only a few millimeters in diameter. The grafting is performed ex vitro at the beginning of spring and it is simpler to execute than micrografting. As rootstock, different types of plant raised during the winter in plastic containers can be used: seedlings, rooted cuttings or micropropagated plants (PREKA; CHERUBINI, 2001). The rootstock is cut at about $10 \mathrm{~cm}$ from the soil, incised longitudinally, and topgrafted with a scion that has the basal end cut to a $\mathrm{V}$-shaped wedge. The scion is then inserted in the stock and tied with parafilm. Grafting establishment will occur in a greenhouse, at high relative humidity and controlled temperature. The major advantage of this type of grafting is that the new plant can be obtained in one-year time. It has high propagation efficiency and some micropropagation laboratories are using it profitably as mass propagation technique.

\section{Mini chip-budding}

It is a sort of herbaceous grafting performed as chip-budding on micropropagated plants grown in plastic container with a stem diameter of about $4-7$ mm (SERRA et al., 2007). It is known as mini chipbudding because of the small size of the rootstock plant and of the cultivar buds, which have being collected from thin shoots or from lateral buds. This technique can be made from September to October or from February to March, utilizing dormant buds collected directly from cultivar mother plants. Grafting could also be made in May-June with cultivar buds collected in the winter and stored at low temperature. Plants grafted in the autumn could be transplanted to the orchard field since the following 
winter, with the benefit of reducing costs and plant price and giving the fruit grower the possibility to raise more efficiently the plant canopy shape. Nursery propagation planning is even more dynamic as well.

\section{Applications of selected microorganisms to nursery plants}

Selected arbuscular mycorrhizal fungi as Glomus mosseae, G. intraradices, among others have the capacity to establish mutualistic symbiosis with the roots of a plant (GIOVANNETTI; AVIO, 2002). Thanks to the symbiosis, fungi benefit of carbohydrates synthesized by the plant and the latter takes advantage from water and nutrients (in particular $\mathrm{P}$ and $\mathrm{N}, \mathrm{Zn}, \mathrm{Ca}$ and $\mathrm{S}$ ) absorbed by the fungi. Mycorrhizal fungi also synthesize natural hormones, which in turn induce useful modifications to roots and plant canopy size and morphology. Moreover, photosynthetic activity of mycorrhized plants can be stimulated as well. Fungi may also be effective in inducing a plant protective barrier against soil pathogens and strengthening the biological balance of the mycorrhizosphere, thanks to the presence of antagonistic bacteria of soil pathogens such as Azospirillum, Rhizobium, Pseudomonas and Bacillus. As a consequence of these peculiarities, mycorrhized plants acquire a significant higher growth potential.

The importance of mycorrhization in nursery practices is stressed by the consideration that artificial substrates commonly used are quite sterile and are practically lacking of useful microorganisms. Thus, the artificial mycorrhization of plants obtained by micropropagation, by cutting and/or by seed, with selected fungi, has shown by now significant positive effects on plant growth and development (TAYLOR; HARRIER, 2003; MORINI; GIOVANNETTI, 2004) and it represents a biotechnology suitable to further improve nursery plant quality. Mycorrhizal symbiosis induced as early as possible in the life of the plant, would produce more appreciable results. Therefore, the first period of the plant growth in the nursery appears to be the best to induce mycorrhization. At this time the plant root system is mainly characterized by young absorbing roots, preferred by fungi to establish the symbiosis. Moreover, root development is still restricted and, as a consequence, only a minimum amount of fungi inoculums can be required for mycorrhization. Finally, mycorrhized plants acquire a strengthened capacity in overcoming field transplantation stresses (GIOVANNETTI; AVIO, 2002).

Some strains of Trichoderma fungus have shown the capability of controlling substrate phytopathogenic fungi as well (PRISA et al., 2013; LOPEZ-BUCIO et al., 2015). In addition, they promote a plant bio-stimulant action by releasing auxins, small peptides, volatiles and other active metabolites into the surround of the plant roots. Subsequently, root branching and nutrient uptake are stimulated for the benefit of plant growth and yield. Up today, Trichoderma has been tested on horticultural plants but it is likely that interesting effects might be attainable also with woody species. Significant improvements of plant growth have also been induced by some bacteria as Azospirillum brasilense Sp245 (VETTORI et al., 2010) applied to micropropagated plants of peach rootstocks, 'Mr.S. $2 / 5$ ' plum (Prunus cerasifera $\mathrm{x}$ P. spinosa) and 'GF 677' hybrid (Prunus persica x P. amigdalus).

The application of biotechnologies based on artificial inoculation of nursery substrates with beneficial microorganisms such as fungi and bacteria represent a new frontier which has the potentiality to induce remarkable innovations on nursery plants quality.

\section{Short time nursery cycles}

Since few years, particular interest has been devoted to techniques suitable to produce maiden trees in short time cycles (NERI et al., 2008), with the purpose of realizing better planning of plants quantity to produce each year, reducing the costs of propagation and producing nursery plants appropriate to satisfy the dynamic requests of the fruit growers, without interfering on nursery plant quality. These objectives have been achieved recently thanks to more advanced and sophisticated techniques of plant propagation and development, either for the propagation of rootstocks (as for instance the micropropagation) or the propagation of varieties (different types of budding and grafting). As a result, techniques as June budding, chip-budding, minichip-budding, herbaceous grafting and container grown plants have opened up new and interesting perspectives in the propagation of peach and plum.

Plants produced by short time cycles (for instance one year) attain clearly smaller size at the end of nursery growth, compared to plants produced according to standard propagation techniques (period of 2 or 3 years). Nevertheless, the cultivation of these plants into plastic containers, allows that growth factors (water and nutrient availability, selected symbiotic microorganisms application, etc.) be controlled and maintained at satisfactory levels, hence inducing the maiden crown to attain a good crown structure and tissue differentiation. Moreover, the possibility of transplanting the plants to the field 
orchard with root ball, guarantees a high plant take and good regrowth potential and precocious fruit production. An alternative which can further reduce nursery propagation cycle is represented by the use of rootstock plants grafted with dormant bud in AugustSeptember transplanted to the definitive orchard field in the autumn to the end of the winter.

\section{Pre-formed plants}

The most important requirements of modern peach and plum orchards are mainly represented by precocious and efficient fruit production. These characters can be fulfilled by using high quality branched maiden plants which are crucial for establishing high-density orchards. Different factors (genotype, variety/rootstock combination vigour, pruning technique, etc.) can affect the precocity of fruit production of a young orchard but the use of nursery maiden plants provided of productive structures (pre-formed plants), is the most important. A meaningful example of pre-formed plants is the well-known apple "knip tree", were the root system (the rootstock) is 3 years-old, the trunk (the variety) is 2 years-old and the crown is 1 year-old. The presence on the crown of healthy and well differentiated branches enables the tree to bear fruits often in the first year after transplanting. For peach and plum the production of pre-formed plants is rather easier and quick since they have a higher natural capacity to produce productive branches, compared to some apple and pear varieties. Basically, pre-formed plants are characterized by the presence of branches developed from axillary buds of the same growth season of the main shoot. Lateral branches allow anticipating in one year the establishment of plant structure and the beginning of fruit production. Outgrowing of axillary buds can be induced by inhibiting the apical dominance exerted by the apex of the growing main shoot, when its height is about 50 $-60 \mathrm{~cm}$. It can be made by hand, removing the shoot apical portion, or chemically applying a mixture of growth regulators (cytokinins and gibberellins) (NERI, 2004; CATALANO; MARTINELLI, 2005).

\section{Container grown plants}

This technique is based on the production of nursery maiden plants grown in small plastic containers, under controlled environmental conditions (light, temperature and humidity) in tunnels or greenhouses. To induce a satisfactory plant growth in a limited volume of substrate, fertirrigation and special substrates can be requested. This type of plant offers two main advantages: reduce the time required to produce the maiden plants to a few months, and extend the period useful for plant transplantation to the orchard field. Generally, plants used as rootstock are produced by micropropagation techniques. After a forcing period of about two months in the container, the mini chip-budding at the beginning of spring is performed. During June, the new plants can be relocated to the field. The technique is not easy to manage and it requires the presence of skilled operators and accurate cultural practices (NERI et al., 2008)

In conclusion, nursery techniques adopted in Europe to propagate peach, nectarines and plum plants, have shown significant changes over time and, today, they have reached the highest level of technology never observed before. However, we cannot ignore that the incessantly evolving requirements of modern fruit orchards will stimulate even more the research and development activities to point out plant propagation systems increasingly advanced, environmentally friendly, inexpensive and able to increase plant production efficiency and to provide plants with biological and agronomical superior traits. 
TABLE 1-Area (ha) and production (t) of peaches and nectarines (FAO, 2016a) and plums (FAO, 2016b) in the 15 major producing countries in 2013 .

\begin{tabular}{|c|c|c|c|c|c|}
\hline \multicolumn{3}{|c|}{ Peaches and Nectarines } & \multicolumn{3}{|c|}{ Plums } \\
\hline Country & Area (ha) & Production $(\mathrm{t})$ & Country & Area (ha) & Production $(\mathrm{t})$ \\
\hline 1- China & 777,400 & $11,954,085$ & 1- China & $1,760,000$ & $6,100,000$ \\
\hline 2-Spain & 84,400 & $1,329,800$ & 2- Serbia & 230,000 & 738,278 \\
\hline 3- Italy & 75,824 & $1,401,795$ & 3-Bosnia and Herz. & 135,168 & 226,898 \\
\hline 4- United States & 49,932 & 964,890 & 4- Romania & 68,008 & 512,459 \\
\hline 5- Greece & 42,800 & 666,200 & 5-Russia & 33,900 & 142,000 \\
\hline 6- India & 37,500 & 250,000 & 6- United States & 33,500 & 210,000 \\
\hline 7- Mexico & 34,010 & 161,268 & 7- India & 27,500 & 220,000 \\
\hline 8- Turkey & 29,092 & 637,543 & 8- Turkey & 21,073 & 305,393 \\
\hline 9- Egypt & 25,183 & 281,814 & 9- Ukraine & 19,200 & 186,300 \\
\hline 10-Argentina & 24,998 & 291,804 & 10-Chile & 18,554 & 306,354 \\
\hline 11- North Korea & 21,500 & 118,000 & 11- Poland & 18,203 & 102,402 \\
\hline 12- Iran & 21,463 & 514,986 & 12- France & 17,443 & 170,960 \\
\hline 13-Algeria & 19,407 & 192,203 & 13-Algeria & 16,803 & 128,786 \\
\hline 14- Chile & 19,185 & 369,786 & 14- Argentina & 16,655 & 153,057 \\
\hline 15- Brazil & 18,091 & 217,706 & 15- Spain & 16,600 & 172,400 \\
\hline
\end{tabular}



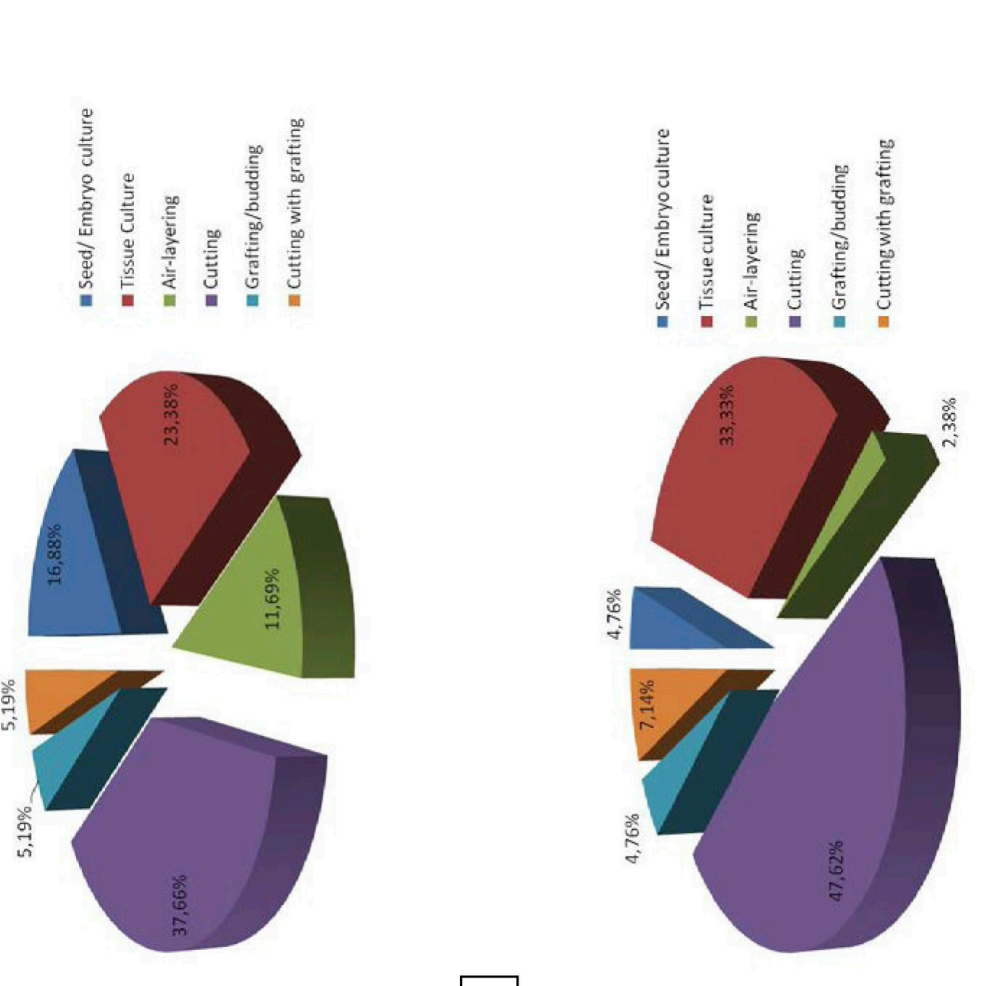

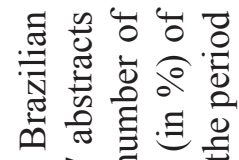

으음흐

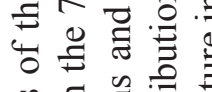

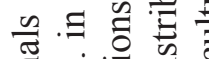

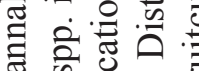

纺

$\exists$ 넝정

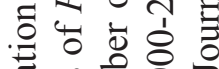

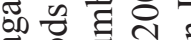

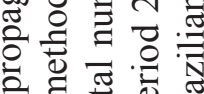

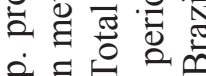

各.0气

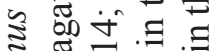

\$

¿

ธี ᄈ 응

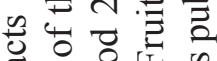

م

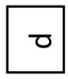

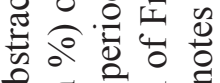

๘ $\Xi$ ฮี

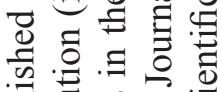

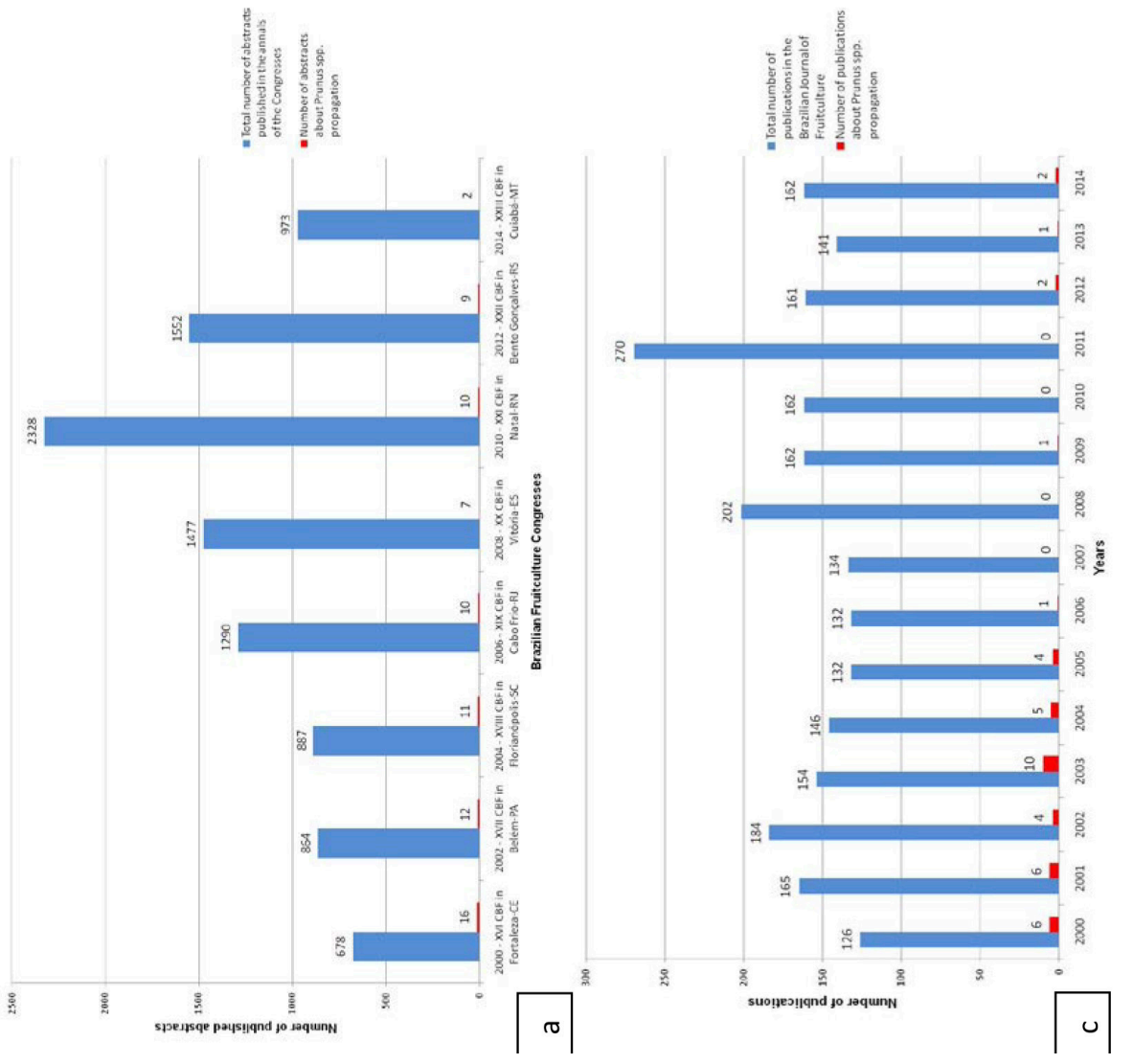

를 है

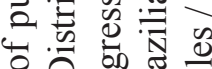

司

으워

莳冚导

궁

ㅊํㅇ킄.

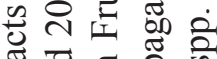

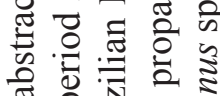

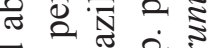

ठ छ

雪

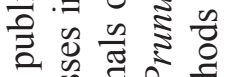

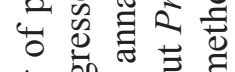

ธิ

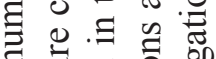

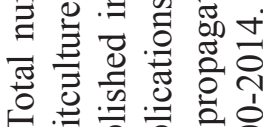

๙

岳 


\section{REFERENCES}

ALMADA, R.; ARISMENDI, M.J.; PIMENTEL, P.; ROJAS.; HINCHSEN, P.; PINTO, M.; SAGREDO, B. Class 1 non-symbiotic and class 3 truncated hemoglobin-like genes are differentially expressed in stone fruit rootstocks (Prunus L.) with different degrees of tolerance to root hypoxia. Tree Genetics \& Genomes, Heidelberg, v.9, p.1051-1063, 2013.

ALMEIDA, C.B.; SOUZA, A.G.; ARGENTA, J.C.; FACHINELLO, J.C.; BIANCHI, V.J. The effect of rootstocks on the vigor, yield, and fruit quality of Maciel peach trees. Revista de Ciências Agrárias, Belém, v.58, p.301-307, 2015.

AMBROSIO PERRET \& CIA. Estabelecimento de fructicultura. Pelota: Quinta Bom Retiro, 1937. $89 \mathrm{p}$.

ARBELOA, A.; DAORDEN, M.E.; GARCÍA, E.; ANDREU, P.; MARIN, J.A. In vitro culture of 'Myrobalan' (Prunus cerasifera Ehrh.) embryos. HortScience, Alexandria, v.44, p.1672-1674, 2009.

BARBA，M.; BASSI，D.; CATARA，A.; TRIBULATO, E.. Produzione de nuove accessioni nel rispetto degli standard richiesti dalle normative per la commercializzazione e certificazione del materiale vivaistico. In: SAVINO, V. et al., Certificazione delle produzioni vivaistiche. Locorotondo: Univerisità Degli Studi di Bari, 1999. p.68-85.

BARBA, M.; CUPIDI, A.; LORETI, S.; FAGGIOLI, F.; MARTINO, L. In vitro micrografting: a technique to eliminate peach latent mosaic viroid from peach. Acta Horticulturae, The Hague, n.386, p.531-535, 1995.

BIANCHI, V.J.; MAYER, N.A.; CASTRO, L.A.S. Produção de mudas. In: CARVALHO, F.L.C., RASEIRA, M.C.B., PEREIRA, J.F.M. Pessegueiro. Brasília, DF: Embrapa, 2014. p.225-249.

BRASIL. Ministério da Agricultura, Pecuária e Abastecimento. Regras para análise de sementes. Brasília, DF: Secretaria de Defesa Agropecuária, MAPA/ACS, 2009. 399p.
CAMPOS, R.V.; BIANCHI, V.J.; ROCHA, P.S.G.; SCHUCH, M.W.; FACHINELLO, J.C. Enraizamento in vitro do porta-enxerto de Prunus cv. Mr. S. 1/8: concentrações de IBA em meio de cultura acrescido de ágar ou vermiculita. Bioscience Journal, Uberlândia, v.23, p.60-65, 2007.

CASTRO, L.A.S.; MAYER, N.A. Mirabolano 29C: obtenção de porta-enxertos clonais por mergulhia aérea. Pelotas: Embrapa Clima Temperado, 2009. 10p. (Circular Técnica, 79).

CASTRO, L.A.S.; MEDEIROS, A. R. M. de. Uso da alporquia na propagação da ameixeira européia cv. Stanley (Prunus domestica). Pelotas: Embrapa Clima Temperado, 2007. 20p. (Boletim de Pesquisa e Desenvolvimento, 60).

CASTRO, L.A.S.; SILVEIRA, C.A.P. Propagação vegetativa do pessegueiro por alporquia. Revista Brasileira de Fruticultura, Jaboticabal, v.25, n.2, p.368-370, 2003.

CATALANO, L.; MARTINELLI, A. Il vivaismo si aggiorna fra nuove tecniche di propagazione e normative di processo. Frutticoltura, Bologna, v.12, p.28-35, 2005.

COUTO, M.; OLIVEIRA, R.P.; FORTES, G.R.L. Multiplicação in vitro dos porta-enxertos de Prunus sp. 'Barrier' e 'Cadaman'. Revista Brasileira de Fruticultura, Jaboticabal, v.26, n.1, p. 5-7, 2004.

DAMIANO, C.; LA STARZA, S.R.; MONTICELLI, S.; GENTILE, A.; CABONI, E.; FRATTARELLI, A. Propagation of Prunus and Malus by temporary immersion. In: HVOSLEF-EIDE A.K. AND PREIL W. (Ed.). Liquid culture systems for in vitro plant propagation. Netherlands: Springer, 2005. p.243251.

DI VAIO, C.; BUCCHERI, M.; CIRILLO, C. Impiego della solarizzazione e della bromurazione del terreno nel reimpianto del pesco: effetto sullo sviluppo vegetativo di astoni in vivaio. In: CONVEGNO NAZIONALE LAPESCHICOLTURA MERIDIONALE DI FRONTE ALLE NUOVE ESIGENZE DI MERCATO, 3., 2001, Metaponto. Atti... p.159-167.

DUTRA, L.F.; KERSTEN, E.; FACHINELLO, J.C. época de coleta, ácido indolbutírico e triptofano no enraizamento de estacas de pessegueiro. Scientia Agrícola, Piracicaba, v.59, n.2, p.327-333, 2002. 
FAO. Area harvested and production of peach and nectarines in 2013. Roma: Fao. 2016a. Disponível em: $\leq$ http://faostat3.fao.org/download/Q/QC/E $>$. Acesso em: 26 abr. 2016.

FAO. Area harvested and production of plums and sloes in 2013. Roma: Fao. 2016b. Disponível em: <http://faostat3.fao.org/download/Q/QC/E $>$. Acesso em: 26 abr. 2016.

FIDEGHELLI, C.; LORETI, F.; ANCARANI, V.; FEI, C.; GODINI, A.; GIOVANNINI, D.; GRANDI, M.; LIVERANI, A.; LUGLI, S.; PALASCIANO, M.; MASSAI, R.; SANSAVINI, S.; POZELLA, M. (Ed.). Monografia dei portinnesti dei fruttiferi. Roma: Ministero delle Politiche Agricole Alimentari e Forestali - Regioni, Liste di orientamento varietale dei fruttiferi, 2009. (Progetto finalizzato)

FIORINO, P.; MATTII, G.B. The role of Prunasin in "collapse" of rooted peach cutting. Advances in Horticultural Science, Florence, n.1, p.11-14, 1992.

FRANZON, R.C.; RASEIRA, M.C.B. Origem e história do pessegueiro. In: CARVALHO, F.L.C., RASEIRA, M.C.B., PEREIRA, J.F.M. Pessegueiro. Brasília, DF: Embrapa, 2014. p.19-23.

GIOVANNETTI, M.; AVIO, L. Biotechnology of arbuscular mycorrhizas. In: KHACHATOURIANS G.G.; ARORA D. K. (Ed.). Applied mycology and miotechnology. Amsterdam: Agriculture and Food Production, 2002. p.275-310.

GRIBAUDO, I.; RESTAGNO, M.; VITTORINO, $\mathrm{N}$. Vented vessels affect growth rate of in vitro Vitis vinifera cv. Nebbiolo. Acta Horticulturae, The Hague, v.616, p.129-133, 2003.

HARTMANN, H.T.; KESTER, D.E.; DAVIES JÚNIOR, F.T.; GENEVE, R.L. Plant propagation: principles and practices. $7^{\text {th }}$ ed. New Jersey: Prentice Hall, 2002. 880p.

HASSANKHAH, A.; VAHDATI，K.; LOTFI, M.; MIRMASOUMI, M.; PREECE, J.; ASSAREH, M.A. Effects of ventilation and sucrose concentrations on the growth and plantlet anatomy of micropropagated persian walnut plants. International Journal of Horticultural Science and Technology, Tehran, v.1, n.2, p.111-120, 2014.
IBGE. Cidades @: Rio Grande do Sul. 2016. Disponível em: $<$ http://cidades.ibge.gov.br/xtras/ uf.php?lang $=\&$ coduf $=43 \&$ search $=$ rio-grande-dosul>. Acesso em: 26 abr. 2016.

KATAN, J.; DEVAY, J.E. Soil solarization: historical perspectives, principles, and uses. In: KATAN J.; DEVAY J.E. (Ed.). Soil solarization. Boca Raton: CRC Press, 1991. section I, p.23-39.

KRISHNA, H.; ALIZADEH, M.; SINGH. D.; SINGH. U.; CHAUHAN, N.; EFTEKHARI, M.; SADH, R. Somaclonal variations and their applications in horticultural crops improvement. 3 Biotech, v.6, n.1, p.54, 2016.

LÓPEZ-BUCIO, J.; PELAGIO-FLORES, R.; HERRERA-ESTRELLA, A. Trichoderma as biostimulant: exploiting the multilevel properties of a plant beneficial fungus. Scientia Horticulturae, Amsterdam, n.196, p.109-123, 2015.

LU, Z.X.; SOSSEY-ALAOUI, K.; REIGHARD, G.L.; et al. Development and characterization of a codominant marker linked to root-knot nematode resistance, and its application to peach rootstock breeding. Theoretical and Applied Genetics, Heidelberg, v. 99, p. 115-122, 1999.

MARTINS, A.S.; BIANCHI, V.J.; FACHINELLO, J.C. Periodos de estratificação e concentrações de giberelina na emergência de plântulas de portaenxertos de pessegueiro. Ambiência, Guarapuava, v.7, p.501-514, 2011.

MAYER, N.A.; BIANCHI, V.J.; CASTRO, L.A.S Porta-enxertos. In: CARVALHO, F.L.C., RASEIRA, M.C.B., PEREIRA, J.F.M. Pessegueiro. Brasília, DF: Embrapa, 2014. p.173-223.

MAYER, N.A.; PEREIRA, F.M. Métodos de propagação do porta-enxerto 'Okinawa' e espaçamentos: efeitos no diâmetro do tronco, fenologia e produção de gemas em pessegueiros 'Aurora-1'. Revista Brasileira de Fruticultura, Jaboticabal, v.30, n.2, p.560-565, 2008.

MAYER, N.A.; PEREIRA, F.M. Produtividade de pessegueiros 'Aurora-1' em diferentes espaçamentos e métodos de propagação do porta-enxerto 'Okinawa'. Bragantia, Campinas, v. 71, n. 3, p.372-376, 2012. 
MAYER, N.A.; PEREIRA, F.M.; BARBOSA, J.C.; KOBA, V.Y. Distribuição do sistema radicular o pessegueiro 'Okinawa' propagado por sementes e por estacas herbáceas. Revista Brasileira de Fruticultura, Jaboticabal, v.29, n.3, p.699-704, 2007.

MAYER, N.A.; PEREIRA, F.M.; NACHTIGAL, J.C. Propagação do umezeiro (Prunus mume Sieb \& Zucc.) por estaquia herbácea. Revista Brasileira de Fruticultura, Jaboticabal, v.23, n.3, p.673-676, 2001.

MAYER, N.A.; REIGHARD, G.L.; BRIDGES, W. Peach rootstock propagation under intermittent mist system. Acta Horticulturae, The Hague, n.1084, p.53-62, 2015.

MAYER, N.A.; UENO, B.; ANTUNES, L.E.C. Seleção e clonagem de porta-enxertos tolerantes à morte-precoce do pessegueiro. Pelotas: Embrapa Clima Temperado, 2009. 13p. (Comunicado Técnico, 209).

MAYER, N.A.; UENO, B.; FISCHER, C.; MIGLIORINI, L.C. Propagação vegetativa de frutíferas de caroço por estacas herbáceas em escala comercial. Pelotas: Embrapa Clima Temperado, 2013. 55p. (Boletim de Pesquisa e Desenvolvimento, 195).

MAYER, N.A; ANTUNES, L.E.C. Diagnóstico do sistema de produção de mudas de Prunóideas no Sul e Sudeste do Brasil. Pelotas: Embrapa Clima Temperado, 2010. 52p. (Documentos, 293).

MAYER, N.A; UENO, B. A morte-precoce do pessegueiro e suas relações com porta-enxertos. Pelotas: Embrapa Clima Temperado, 2012. 42p. (Documentos, 359).

MESCHIMIDT, A.A.; BIANCHI, V.J.; ZANANDREA，I.; MATINAZZO，E.G.; RADMANN, E.B.; BACARIN, M.A. Trocas gasosas e atividade antioxidante de portaenxertos de Prunus spp. submetidos ao estresse seca e alagamento. Revista de la Facultad de Agonomía, La Plata, v.114. n.1, p. 71-81, 2015.

MILLER, P.J.; PARFITT, D.E.; AND WEINBAUM, S.A. Outcrossing in peach. HortScience, Alexandria, v.24, n.02, p.359-360, 1989.
MINDÊLlO NETO, U.R.; TELLES, C.A.; BIASI, L.A. Enraizamento adventício de estacas semilenhosas de cultivares de pessegueiro. Scientia Agrária, Curitiba, v.9, n.4, p.565-568, 2008.

MINDÊLLO NETO, U.R.; TELLES, C.A.; BIASI, L.A. Enraizamento de estacas lenhosas de ameixeiras tratadas com ácido indolbutírico. Ciência Rural, Santa Maria, v.36, n.2, p.448-452, 2006.

MORINI, S. Stato attuale della produzione di portinnesti mediante micropropagazione. Frutticoltura, Bologna, n.12, p.33-36, 2004.

MORINI, S.; GIOVANNETTI, E. La micorrizazione, una biotecnologia per la produzione in vivaio di piante arboree da frutto di elevata qualità. Frutticoltura, Bologna, n.12, p.43-46, 2004.

MUDGE, K.; JANICK, J.; SCOFIELD, S.; GOLDSCHMIDT, E.E. A history of grafting. In: JANICK, J. Horticultural reviews. Hoboken: John Wiley \& Sons, 2009. v.35, p.437-493.

MURRI, G.; MASSETANI, F.; GIUSTI, S.; FUNARI, A.; NERI, D. Diverse combinazioni d'innesto del susino Fortune in terreno stanco. Frutticoltura, Bologna, n.5, p.42-50, 2012.

NACHTIGAL, J.C. Obtenção de porta-enxertos 'Okinawa' e de mudas de pessegueiro (Prunus persica (L.) Batsch) utilizando métodos de propagação vegetativa. 1999. 165f. Tese (Doutorado em Agronomia) - Faculdade de Ciências Agrárias e Veterinárias, Universidade Estadual Paulista, Jaboticabal, 1999.

NERI, D. La formazione delle piante da frutto in vivaio. Frutticoltura, Bologna, n.12, p.26-31, 2004.

NERI, D.; MASSETANI, F.; DALMONTE, C. Riduzione del ciclo di vivaio. In: CONVEGNO NAZIONALE SULLA PESCHICOLTURA MERIDIONALE, 6., 6-7 marzo, 2008, Caserta. Atti... 2008.

OKIE, W.R. Prunus domestica - european plum, Prunus salicina - japanese plum. In: JANICK, J.; PAULL, R.E. The encyclopedia of fruit $\&$ nuts. Cambridge: Cambridge University Press, 2006b. p.694-705. 
OKIE, W.R. Prunus persica: peach and nectarine. In: JANICK, J.; PAULL, R.E. The encyclopedia of fruit $\&$ nuts. Cambridge: Cambridge University Press, 2006a. p.717-727.

PAULA, L.A.; BIANCHI, V.J.; GOMES, C.B.; FACHINELLO, J.C. Reação de portaenxertos de pessegueiro a Meloidogyne incognita. Revista Brasileira de Fruticultura, Jaboticabal, v.33, n.2, p.680-684, 2011a.

PAULA, L.A.; BIANCHI, V.J.; NOGUEIRA, L.R.; BARROS, W.S.; FACHINELLO, J.C. Transferabilidade e ligação de marcadores moleculares em uma população de Prunus persica ('Capdeboscq' x 'Flordaguard'). Revista Brasileira de Agrociência, Pelotas, v.17, p.321-325, 2011 b.

PEREIRA, F.M.; MAYER, N.A. Pessegueiro: tecnologias para a produção de mudas. Jaboticabal: Funep, 2005. 65p.

PREECE, J.E. A century of progress with vegetative plant propagation. HortScience, Alexandria, v.38, n.5, p.1015-1025, 2003.

PREKA P.; CHERUBINI S. Tecniche di innesto erbaceo per la propagazione di piante arboree da frutto. Frutticoltura, Bologna, n.5, p.39-41, 2001.

PRISA, D.; SARROCCO, S.; BURCHI, G.; VANNACCI, G. Use of Trichoderma asperellum 2046 in new 'tailor made' substrates for ornamental plants. Journal of Plant Pathology, Bari, v.95, p.57, 2013.

RADCHUK, V.V.; KORKHOVOY, V.I. The rolB gene promotes rooting in vitro and increases fresh root weight in vivo of transformed apple scion cultivar "Florina". Plant Cell Tissue and Organ Culture, Berlin, v.81, p.203-212, 2005.

RADMANN, E.B.; BIANCHI, V.J.; FACHINELLO, J.C.; FERREIRA, L.V.; OLIVEIRA, R.P.. In vitro multiplicaton of 'Flordaguard' rootstock: cytokinin source and concentration effects, explant orientation and period of permanence in the culture medium. Brazilian Archives of Biology and Technology, Curitiba, v.54, p.25-34, 2011.
RADMANN, E.B.; BIANCHI, V.J.; OLIVEIRA, R.P.; FACHINELLO, J.C.. Multiplicação in vitro e alongamento de brotações micropropagadas do porta-enxerto 'Tsukuba 1' (Prunus persica L.). Revista Brasileira de Fruticultura, Jaboticabal, v.31, p.656-663, 2009a.

RADMANN, E.B.; BIANCHI, V.J.; SOUZA, T.M.; FACHINELLO, J.C.; OLIVEIRA, R.P.. Influência da composição do meio de cultura e do tipo de explante na micropropagação do porta-enxerto de Prunus sp. 'GxN-9'. Scientia Agrária, Curitiba, v.10, p.95-101, 2009b.

RADMANN, E.B.; FEIJO, A.R.; GOULART, R.C.; FISCHER, D.L.O.; BIANCHI, V.J. Interação entre o genótipo e aib no enraizamento de estacas semilenhosas de portaenxertos de pessegueiro. Nativa, Sinop, v.2, p.129-133, 2014a.

RADMANN, E.B.; GALLO, C.M.; RITTERBUSCH, C.W.; BIANCHI, V.J.; FERNANDO, J.A.; PETERS, J.A.. Enraizamento in vitro e aclimatização do porta-enxerto de ameixeira 'MR. S. 2/5'. Plant Cell Culture \& Micropropagation, Lavras, v.10, n.2, p.21-31, 2014b.

RAYYA, M.S.A.; KASSEM, N.E.; ALI, E.A.M. Rooting induction of soft wood and almond microcutting using Agrobacterium rhizogenes. Research Journal of Agriculture \& Biological Sciences, Pakistan, v.6, n.1, p.40, 2010.

REMORINI, D.; MASSAI, R.; LORETI, F.. Effetto del portinnesto e della gestione della chioma sulla qualità dei frutti di pesco. Futticoltura, Bologna, n.12, p.43-48, 2005.

ROCHA, P.S.G.; BIANCHI, V.J.; SCHUCH, M.W.; MISTURA, C.C.; FACHINELLO, J.C. Multiplicação e enraizamento in vitro do porta-enxerto de Prunus cv. Mr.S. 2/5. Revista Científica Rural, Bagé, v.12, p.14-21, $2007 \mathrm{~b}$.

ROCHA, P.S.G.; SCHUCH, M.W.; BIANCHI, V.J.; FACHINELLO, J.C. Qualidade da luz na micropropagação do porta-enxerto de Prunus cv. Mr. S. 2/5. Bioscience Journal, Uberlândia, v.23, p.32-40, 2007a. 
ROSSI, C.E.; FERRAZ, L.C.C.B.; MONTALDI, P.T. Resistência de frutíferas de clima subtropical e temperado a Meloidogyne incognita raça 2 e $M$. javanica. Arquivos do Instituto Biológico, São Paulo, v.69, n.2, p.43-49, 2002.

SANSAVINI, S.; BASSI, D.; MANUCCI, C.; CORREALE, R.; GRANDI, M.. Nuovi portinnesti del pesco: preliminari risultati com la nettarina Ambra e possibili alternative al GF 677. Frutticoltura, Bologna, n.12, p.48-56, 2004.

SAVINO, V. Certificazione: un passo avanti decisivo verso la riorganizzazione. Frutticoltura, Bologna, n.12, p.9-12, 2006.

SCALZO, J.; CAPOCASA, F.; D'ADDARIO, M.; DIAMANTI, J.; MEZZETTI, B. L'influenza del portinnesto sulla qualità nutrizionali di pesche $\mathrm{e}$ susine. Frutticoltura, Bologna, n.3, p.56-63, 2006.

SCHMITZ, J.D.; PASA, M.S.; FISCHER, D.L.O.; FACHINELLO, J.C.; BIANCHI, V.J.. Desempenho de porta-enxertos em diferentes sistemas de cultivo na produção de mudas do pessegueiro 'Chimarrita'. Revista Ceres, Viçosa, MG, v.61, p.293-297, 2014.

SERRA, S.; LAIMER, P.; MUSACCHI, S. Applicazione della tecnica del mini chip budding in pesco e ciliegio. Italus Hortus, Firenze, v.14, 2007. Suplemento 2 .

SHARPE, R.; HESSE, C.; LOWNSBERY, B.; PERRY V-G.; HANSEN, C-J. Breeding peaches for root-knot nematodes resistance. Journal of the American Society for Horticultural Science, Mount Vernon, v.94, p.209-212, 1969.
SOUZA, A.G.; SMIDERLE, O.J.; SPINELLI, V.M.; SOUZA, R.O.; BIANCHI, V.J. Correlation of biometrical characteristics of fruit and seed with twinning and vigor of Prunus persica rootstocks. Journal of Seed Science, Londrina, v.38, n.4, p.332328, 2016.

SOUZA, A.L.K. A clonagem de porta-enxertos afeta o comportamento inicial a campo de plantas de pessegueiro? 2014. 99f. Tese (Doutorado em Agronomia) - Universidade Federal de Pelotas, Pelotas, 2014.

TAYLOR, J.; HARRIER, L.A. Beneficial influences of arbuscular mycorrhizal (AM) fungi on the micropropagation of woody and fruit trees. In: JAIN, S.M.; ISHII, K. (Ed.) Micropropagation of woody trees and fruits. Netherlands: Kluwer Academic Publishers, 2003. p.129-150.

TOFANELLI, M.B.D.; RODRIGUES, J.D.; ONO, E.O. 2,6-Di-hidroxiacetofenona e tipo de corte basal no enraizamento de estacas semi-lenhosas de pessegueiro 'Okinawa'. Ciência Rural, Santa Maria, v.35, n.2, p.462-464, 2005.

TOMAZ, Z.F.; SCHUCH, M.W.; PEIL, R.M.N.; TIMM, C.R.F. Desenvolvimento de porta-enxertos de pessegueiro obtidos por miniestacas, em duas épocas, e sistema de cultivo sem solo. Revista Brasileira de Fruticultura, Jaboticabal, v.36, n.4, p.988-995, 2014.

VETTORI, L.; RUSSO, A.; FELICI, C.; FIASCHI, G.; MORINI S.; TOFFANIN, A. Improving micropropagation: effect of Azospirillum brasilense Sp245 on acclimatization of rootstocks of fruit tree. Journal of Plant Interactions, Boulder, p.1-11, 2010 . 